\title{
BUILDING INEQUALITY: WAGE DISPARITY BETWEEN BANGLADESHI AND THAI GUESTWORKERS IN SINGAPORE'S CONSTRUCTION INDUSTRY
}

\author{
A Thesis \\ Presented to the Faculty of the Graduate School \\ of Cornell University \\ in Partial Fulfillment of the Requirements for the Degree of \\ Master of Science
}

by

Katie Elizabeth Rainwater

May 2015 



\begin{abstract}
Although national origin specific wage differentials are prevalent in many guestworkforces, this topic has not received attention in academic scholarship. In this paper, I draw from in-depth interviews to account for a wage differential between first-time Thai and Bangladeshi construction industry guestworkers in Singapore. I argue that Thai workers' higher wages are an outcome of the Thai state's comparatively better regulatory provisions (including the imposition of a minimum wage for Thai guestworkers) as well as differences in the sub-national groups for whom Singaporean construction jobs meet the dual criteria of being appealing and attainable. Whereas in Thailand, Singaporean construction jobs have limited appeal beyond poorly educated peasants originating in communities with a culture of international labor migration, in Bangladesh, migrants originate in the rural middle-class. Cognizant of differences in the class specific attitudes that the different migrant groups have toward work, many Singaporean employers prefer to hire "hardened Thai rice farmers" instead of Bangladeshi "school-boys".
\end{abstract}




\section{BIOGRAPHICAL SKETCH}

Katie Rainwater earned her BA in Anthropology from the University of North Carolina Chapel-Hill in 2005. She earned her MA in Southeast Asian Studies from the National University of Singapore in 2012. 


\section{ACKNOWLEDGEMENTS}

This research was partially supported by a Graduate Student Research grant from the Institute of Social Sciences Migration Cluster and an Einaudi Center Travel Grant. I am grateful for this funding, for the support of my committee and for the participation of my informants. 
TABLE OF CONTENTS

BIOGRAPHICAL SKETCH

iii

ACKNOWLEDGEMENTS

iv

TABLE OF CONTENTS

V

INTRODUCTION

THEORETICAL OVERVIEW

CASE SELECTION AND METHODOLOGY

HISTORICAL BACKGROUND

THE PRODUCTION OF WAGE DISPARITY

THE SOCIAL ORGANIZATION OF WORK

CONLCUSION

BIBLIOGRAPHY 


\section{INTRODUCTION}

In 2009, Jerun left his home in rural Northeastern Thailand to begin work as a welder in a suburban Singaporean factory which fabricated steel structural frames for use in the construction of high rise buildings. His starting daily salary was SGD 23 per day — a pittance in a state boasting more millionaires per capita than almost anywhere in the world (Linton 2014). However, Jerun could at least find solace in the fact that his wages were not the lowest in the factory. The Bangladeshi and Indian welders who began work at the same time as Jerun were only earning SGD 18 per day. Jerun's higher salary did not serve as compensation for experience or education credentials. Jerun and his South Asian colleagues were equally inexperienced in welding and had received identical rudimentary training in the trade in a mandatory, self-funded course, the curriculum of which was designed by Singaporean authorities to teach prospective construction workers "craft-skills competency" and "essential trade knowledge" (Building and Construction Authority [BCA] 2014). With regard to formal education, Jerun was considerably less qualified than his South Asian colleagues. When Jerun took the trade certification exam which includes a practical and a theoretical component (BCA, 2014) — he had only a sixth grade education. ${ }^{1}$ In contrast, all of his South Asian co-workers had completed at least the ninth grade, a consequence of a Singaporean government policy which specifies English, Chinese and Thai as the languages of the Singaporean construction industry (Lim 1999). ${ }^{2}$ Whereas Jerun was

\footnotetext{
${ }^{1}$ When first introduced in 1992 ("More skilled workers" 1992 ), the trade certification test for foreign workers included only a practical component. The theoretical component of the certification exam was introduced with the intention of producing a more educated, high-skilled workforce or to preclude farmers like Jerun from getting a job (Vasoo, 1999a).

${ }^{2}$ The inclusion of Thai as a language of Singapore's construction industry is a testament to their early predominance in the industry. When Singapore, first opened its door to non-Malaysian foreign workers in 1980, Thais quickly became the predominate source of labor. Ofori's data from the BCA's predecessor organization, the Construction Industry Development Board, suggests a 3: 1 Thai to other non-traditional source country worker ratio in the early 1990s (1997). By the late 1990s, figures cited in the Straits Times suggest that there were relatively equal numbers of Thais, Indians and Bangladeshis in the industry (Vasoo, 1998b; Kam, 1999; Tang, 1998; De Souza, 1998).
} 
permitted to take the certification exam in his native tongue, South Asian prospective migrants are required to sit for the exam in English, necessitating that prospective workers from these countries must have relatively high levels of education. Moreover, Jerun's inability to communicate in English would also seemingly devalue his labor power relative to South Asians in an industry in which English is the worksite lingua franca for communication regarding safety and labor processes (Loosemore \& Lee 2002).

Pay disparities between first-time Thai and first-time Bangladeshi workers pervade Singapore's construction industry. Nationality is an important criterion for determining the rate at which all first-time construction workers in Singapore are paid. The national origin specific wage hierarchy which pervades Singapore's construction industry has not been subjected to scrutiny in critical scholarship on the industry's workforce which generally examines the subject position of migrant construction workers of a single national group vis-a-vis Singaporean citizens or firms. ${ }^{3}$ The economic and social relations prevailing between guestworkers of diverse national origin and how these multiple national groups differentially relate to Singaporean construction firms has been left unexamined. This gap is replicated in the literature on guestworkers more generally. Guestworker programs, such as Singapore's Work Permit Program, enable employers to import foreign nationals on a temporary basis and to repatriate them when their services are no longer required. In order to circumvent dependence on any single labor source, guestworker program regulations often permit employers some degree of discretion when choosing from which state(s) to source their labor. As a consequence, many guestworkforces are comprised of workers from

\footnotetext{
${ }^{3}$ On Thai workers in Singapore see Kitiarsa (2013), Kong (2007), Sullivan, Gunesekaran, \& Siengtai (1992), and Wong (2000). On Bangladeshi workers in Singapore see Abdullah (2005, 2001), Bal (2013), Fee \& Rahman (2006), Rahman\& Fee (2005) and Rahman (2009, 2003). On Chinese workers in Singapore see Low, Liu \&Soh (2008) and Mei (2010). On Indian workers see Hamid (2015).
} 
more than one national group. In some guestworker programs, national origin is an important determination of workers' wages, yet the reason for this has not been sufficiently explored in academic literature.

How and why do pay differentials emerge in guestworkforces composed of workers of variant national origin? What implications do national origin based scales of pay have for the social organization of work in guestworker labor regimes? My paper considers these questions by drawing from fieldwork on Thai and Bangladeshi Work Permit holders in Singapore's construction industry. I argue that the wage disparity between Thai and Bangladeshi construction workers in Singapore is an outcome of the uneven development of capitalism. By uneven development I refer to the ways in which social formations, while integrated into the same world economic system, exhibit quantitative inequality (in terms of the rate of economic growth) and qualitative difference (in terms of history, culture, class formation and so forth) (Rosenberg 2006). The unevenness that prevails between Thailand and Bangladesh affects two processes relevant to the production of the wage disparity between Thai and Bangladeshi construction workers in Singapore. First, the Thai and Bangladeshi states have adopted divergent approaches to governing the export of migrant labor. Whereas Bangladesh — heavily dependent upon remittances as a source of foreign exchange currency (Siddique, Selvanathan \& Selvanathan 2012) — is intent on maximizing the export of male workers, Thailand has attempted to implement a modicum of protections for its migrant workforce including a minimum wage (currently SGD 23 per day) for Thai construction workers in Singapore. Second, the unevenness that prevails between Bangladesh and Thailand has resulted in differentiation in the subsets of the Bangladeshi and Thai populations for whom Singaporean construction jobs meet the dual criteria of being both appealing and attainable. Whereas in Thailand, Singaporean 
construction jobs only enjoy wide appeal among poorly educated peasants originating in areas with strong cultures of international labor migration, in Bangladesh, Singaporean construction jobs are only attainable to those who are at least middle-class and therefore in possession of the educational and financial capital required to pass the trade certification test and pay the hefty employment agency fee required to arrange work with a Singaporean construction firm. Yet somewhat ironically, it precisely because of Bangladeshis' higher levels of education and their middle-class backgrounds, that many Singaporean construction firms are willing to pay a premium for the labor power of — in the words of one employment agent — "hardened [Thai] rice farmers" whose capacity to labor is perceived as superior to that of Bangladeshi "schoolboys".

Not only does the unevenness between Bangladesh and Thailand contribute to the creation of pay differentials in Singapore's multinational construction guestworkforce, but the social organization of construction work in Singapore may in turn contribute to further unevenness in economic development between Bangladesh and Thailand. One of the most important consequences of the lower price of South Asian labor is the disproportionate representation of these workers in "worker-supply companies" (labor-only subcontractors). These firms ostensibly profit by supplying temporary labor to firms at a flat rate that covers the management of the recruitment, payroll, lodging and transportation of workers. Yet an important source of supply-company's profit is actually the illegal and substantial fees that they charge workers for their jobs. Because these feeds often exceed workers' earnings, supply company employment represents the net transfer of wealth away from workers — and rural Bangladeshi communities — to Singaporean firms.

Ultimately, I suggest that my research on Thai and Bangladeshi workers in Singapore 
demonstrates the need to refine a conceptual framework for studying multi-national guestworkforces. Whereas critical conceptualizations of guestworker programs have articulated how the labor-receiving state — as a relation of production — enables firms to reduce labor costs by exploiting unevenness in economic development between the labor-source and the labor-receiving states through legal mechanisms that decommodify migrant labor power and outsource facets of social reproduction (Burawoy 1976; Miles 1987), these general theories of capital-guestworker relations fail to account for variation in the terms in which guestworkers from a diverse array of labor- sources states enter into wage relations in labor-receiving states. Examination of the way in which unevenness in economic development between labor-source states contributes to the constitution of unequal wage relations among guestworkers and the implications of this relationship for the social organization of work is necessary in order to understand how multinational guestworkforces are both produced by and may be contributing to the uneven development of capitalism.

The remainder of this paper is organized as follows. In the first section, I offer a review of relevant literature. In the second section, I introduce the rationale for the case selection and discuss my methodology. In the third section, I provide an overview of Singapore's Work Permit Program and describe how Work Permit Program regulations enable Singaporean construction firms to take advantage of uneven development between labor-source states and Singapore to minimize labor costs. In the fourth section, I discuss the ways in which unevenness in economic development between Thailand and Bangladeshi contributes to the wage differential of Thai and Bangladeshi workers in Singapore. In the fifth section, I argue that one consequence of the national origin based scale of pay for the social organization of work is Bangladeshi workers' disproportionate representation in worker supply companies. Finally, in the conclusion, I discuss 
some of the larger implications of national origin based scales of pay in guestworker labor regimes.

\section{THEORETICAL OVERVIEW}

Since the 1970s, there has been a worldwide proliferation of guestworker programs (Hahamovitch 2011) and today there are nearly 20 million guestworkers in approximately 50 countries worldwide (Surak 2013). National origin specific pay scales are not characteristic of all — or even most - multinational guestworkforces. For example, in the United States, guestworkers hired in the agricultural sector, irrespective of their country of origin, are typically paid the "Adverse Effect Wage Rate" determined by the U.S. Department of Agriculture (Farmworker Justice, n.d.). Nevertheless, national origin specific pay scales are found in a number of states which like Singapore lack strong labor regulations.

One potential framework for explaining the wage differential between Thai and Bangladeshi workers is neoclassical economic theory (see the discussion of this theory in Massey et. al., 1993). Neoclassical economists posit that migration is often an outcome of spatial disparity in concentrations of capital and labor. They articulate two schemas through which migration levels the spatial imbalances prevailing between concentrations of labor and of capital. In the first scenario, in pursuit of higher wages, unskilled workers from areas with a large endowment of labor relative to capital migrate to areas with a large endowment of capital relative to labor. In theory, migration works to level the disparity in wages between the origin and the destination. In the second scenario, in pursuit of higher wages, skilled workers migrate to an area in which their skills are in short supply. In this case, the skilled worker commands higher wages than s/he does in his/her place of origin not as a consequence of a general scarcity of labor but rather as a consequence of a scarcity of employable persons with his/her specific skill set. In 
this case, the migrant's wage level takes into account his/her "human capital" or the degree of investment in education and training (Becker, 1962).

When applied to the case of Singapore, the first scenario fails to explain the wage differential between Thai and Bangladeshi workers because the only wage differential considered by this theory is that which exists in the place of origin as compared to the place of destination. The second scenario which posits that education and training is taken into account in the determination of the wages of skilled migrants initially seems to have more leverage for explaining the national origin specific wage disparity within Singapore's construction industry. Construction industries may follow either a "capital-intensive, human capital intensive and technically dynamic growth path" or a "low-skill, less well-equipped, labor-intensive growth path" (Bosch \& Phillips, 2003). In electing to develop according to the former path, the Singaporean government is attempting to recruit workers that it deems capable of engaging in knowledge-intensive labor processes (BCA 2011, Ofori 2002). As the former Singaporean Minister of State for National Development explained of the mandatory trade certification process that all workers must undergo, "[the test] will further minimize the risk of hiring farmers, fishermen and other unsuitable workers...The requirement would help contractors in the hiring process and distinguish the skilled worker from the farmer who wants to find a job here" (Vasoo, 1999a). Therefore we might surmise that national origin specific wage differences reflect disparity in educational and training between the various national groups. Yet in contrast to human capital theory, it is actually the more poorly-educated Thais who earn higher wages than the more highly-educated Bangladeshis.

I suggest that Robert Miles (1987) and Michael Burawoy's (1976) respective theorizations of guestworker programs are a more fruitful starting point for examining the wage 
disparity that prevails between Bangladeshi and Thai workers. Burawoy (1976, p. 1068), in an article attempting to move migration theory beyond its origins in neoclassical economics, and Miles (1987), in a book-length theorization of unfree labor within capitalism, argue that "migrant labor exists only because of the uneven development of capitalism".

In the context of spatial heterogeneity in economic development, guestworker programs enable firms to avoid increasing the wages of labor within a social formation by allowing for the recruitment of workers from other, less developed social formations (Miles 1987). For firms, the labor-power of guestworkers is less expensive than that of citizen workers for two reasons. First, guestworker program regulations — such as those that preclude guestworkers from migrating with their dependents and that prohibit settlement — relegate many of the costs of labor-power renewal to alternate economies. Second, guestworker program regulations — such as those that restrict guestworker employment to a specific sector or a specific employer — produce guestworkers as disempowered. Miles and Burawoy respectively posit that the labor-receiving state is an essential relation of production because it is the labor-receiving state's regulations that produce guestworker labor power as cheap relative to the labor power of citizens. Yet the laborreceiving state's capacity to enact these regulations is premised upon uneven economic development. If not for inequality in economic growth between social formations, guestworkers — who as a condition of employment must live apart from their dependents and temporarily relinquish their capacity to re-commodify their labor power - could hardly be recruited.

While Miles and Burawoy's work can be fruitfully used to understand wage differentials between guestworkers and citizen workers, they do not provide an account of wage differentials between guestworkers from different national groups. Nevertheless I suggest that their respective accounts can be fruitfully applied to this purpose with a couple of modifications. First like the 
labor-receiving state, the labor-sending state must also be conceptualized as a relation of production contributing to the formation of guestworker labor regimes. Second, uneven development which provides the context that enables guestworker programs to be enacted must be considered more expansively. Instead of exclusively accounting for quantitative inequality (in terms of the rate of economic growth) between the labor-sending state and labor-receiving state which enables the recruitment of the guestworkforce, qualitative differences ( in terms of history, culture, class formation and so forth) between labor source states must be taken into account (Rosenberg 2006).

\section{CASE SELECTION AND METHODOLOGY}

Singapore's 320,000 strong construction workforce is composed entirely of guestworkers (Ministry of Manpower, 2014a). Bangladesh contributes approximately 60,000 men to this workforce, while there are roughly 30,000 Thais. ${ }^{4}$ Workers from India and China are also present in Singapore's industry in large numbers (Tan 2013a, 2013b). More recently, in response to a perceived labor shortage, Singapore has begun encouraging the entry of construction workers from Myanmar, Sri Lanka and the Philippines (Tan 2013a, Tan 2013b, Ong \& Yee 2012). Wages for all first-time construction workers in Singapore are determined with reference to their nationality with Chinese workers receiving the highest wages and Bangladeshis and Indians, the lowest ("First group of" 2013). Of the national groups which comprise Singapore's construction

\footnotetext{
${ }^{4}$ Singapore does not release statistics on foreign workers aggregated according to nationality. These estimates on the number of Thais and Bangladeshis in Singapore were supplied by the Thai Labor Attaché in a June 2011 interview and by the Bangladeshi High Commission in a February 2012 interview. Since mid-2011 and early 2012, the number of Work Permit holders in Singapore's construction industry has increased considerably (by some 60,000 workers) (Ministry of Manpower 2014a). As a consequence of the increased demand for construction labor, at present there are probably more than 60,000 Bangladeshi construction workers in Singapore. The number of Thai workers likely did not increase substantially as the Thai Labor Attaché conveyed that the ranks of Thais interested in working in Singapore are dwindling.
} 
workforce, I have chosen to investigate the wage differential that exists between first-time Bangladeshi and first-time Thai workers for several reasons. First, unlike the other major migrant groups (Chinese and Tamil Indians) in Singapore's construction industry, neither Bangladeshis nor Thais share an ethnic background with one of Singapore's major ethnic groups therefore minimizing the chance that the wage differential is a consequence of ethnic affinity. Second, unlike India and especially China, neither Thailand nor Bangladesh is a major exporter of construction services. In Singapore, the vast majority of Thais and Bangladeshis are employed by firms that do not share their national origin. Third, as described above, the higher wages of Thais is particularly perplexing given their lower levels of education in relation to the Bangladeshis.

I draw from more than 50 semi-structured interviews with Thai and Bangladeshi workers and consulate officials, employment agencies and employers carried out in Singapore in three phases: May - June 2011, September - December 2011 and May - June 2013. I met the majority of my informants by approaching workers at Golden Mile Complex (a popular meeting space for Thai workers) and in Little India (a popular meeting spot for Bangladeshi workers) and asking them to take part in my research. Interviews lasted between thirty minutes and several hours. Sometimes workers were joined by one or more friends for all or part of the interview session. Interviews with Thai workers were conducted in Thai, while interviews with Bangladeshi workers were conducted in English. My research is also informed by friendships that I formed with workers as a volunteer with two migrant worker organizations: Friends of Thai Workers Association (for which I was a volunteer English teacher from 2009 - 2011) and TWC2, for which I authored a report about Bangladeshi workers and employment agency fees (Transient Workers Count Too![TWC2], 2012 ), an experience that required me to interact with many 
Bangladeshi workers. The seven employment agency interviews took place at offices in Golden Mile Complex and Furama City Center. In addition, I interviewed four owners or managers of construction firms that employed Thai and/or Bangladeshi labor. Except for one employer (whom I met when he visited an employment agency where I was conducting an interview), I met the others in the course of everyday life (at a hawker center, at the airport and at a friend's birthday party). ${ }^{5}$

\section{HISTORICAL BACKGROUND}

Singapore first implemented its Work Permit Program (hereafter, WPP) in 1965 when its labor market was dramatically constricted upon expulsion from Malaysia (Kaur 2010). The WPP enabled firms to hire Malaysians (Wong 1997, Fong \& Lim 1992). Yet amid economic development in Peninsular Malaysia as well as Singapore, firms complained of labor shortages. The construction industry, stigmatized by a poor safety record and poor working conditions, especially struggled to attract labor (Ofori 1997, Debrah \& Ofori 1997). Beginning in 1980, the Singaporean government allowed construction firms to hire foreign workers through a revised WPP introduced to enable the import of workers from farther afield than neighboring Malaysia (Wong 1997). This incarnation of the WPP permitted firms to hire labor from designated "nontraditional source countries". This list of countries initially included Bangladesh and Thailand, as well as India, Indonesia, Sri Lanka and the Philippines (Fong 1992, Loh \& Heng 1992). ${ }^{6}$

\footnotetext{
${ }^{5}$ I initially intended to interview more employers. However, my attempts to secure interviews by emailing, calling or visiting construction firms were not successful.

${ }^{6}$ In a 1980 Straits Times article announcing the new program, Bangladeshi is not listed as a designated labor source state (Teo). However, I have concluded that this omission is most likely an oversight, as Bangladesh is listed as an original labor source state in several academic publications (Fong, 1992; Loh \& Heng, 1992) as well as other news articles around the time that the program started ("New work permits"). The composition of designated labor source states has shifted somewhat over the years. Currently, the list of designated labor source states for the construction industry is as follows: India, Sri Lanka, Thailand, Bangladesh, Myanmar and the Philippines (Ministry of Manpower
} 
The regulatory framework of the WPP for the construction industry has been continuously revised over the past three and a half decades as the rationale for importing construction workers has shifted from being conceptualized as a temporary, stop gap measure to the current recognition of foreign workers as a vital component of the construction industry's workforce for the foreseeable future (Ofori 2002, 1997). Shifts in policy notwithstanding, the WPP has consistently facilitated supplying construction firms with inexpensive and transient labor. The ultimate beneficiary of this system is the largest client of Singapore's construction industry, the Singaporean government.

The WPP enables construction firms to take advantage of uneven economic development within Asia to secure low cost labor through two primary mechanisms. First, program regulations externalize the costs of social reproduction with immigration regulations that prevent construction WP holders from migrating with their families and that impose restrictions upon their marriage to Singaporeans (Ng 2011, Employment of Foreign Manpower Act (EFMA), 1990(2009)). In addition, eligibility for employment in Singapore's construction industry as a foreign worker is legally contingent upon remaining below a certain age (50 years for nonMalaysian and 58 years for Malaysians). These regulations reduce the cost of labor by dictating that labor renewal and eldercare occurs in economies in which the cost of food, housing and medical care is significantly lower than in Singapore (Ministry of Manpower 2014b). In addition, savings on the maintenance of the workforce is realized by the WPP requirement that firms provide housing in-kind giving way to economies of scale with worker dormitories (EFMA 1990).

The second mechanism by which the WPP enables firms to secure low cost labor is 
through regulatory mechanisms that prohibit the free circulation of WP holders within Singapore's labor market (EFMA 1990). The Singaporean state disavows minimum wage provisions and instead professes that market-determined logics of pricing prevail with regard to the wages of foreign workers. A bureaucrat in the Ministry of Manpower recently summarized this position as follows: "The Government's basic philosophy is to allow remuneration to be set according to market principles. Employers are free to determine the salary they are willing to pay for a particular job. In the same vein, workers, whether local or foreign, are free to decide if the employment terms or offer suit their needs, and whether to accept or reject the employment offer" (Ministry of Manpower 2013). Yet at the same time that the Ministry of Manpower professes allegiance to free market principles, it establishes regulatory mechanisms that circumvent the free circulation of labor. WPP regulations restrict WP holders' ability to sell their labor power by only permitting them to work in specific sectors for the employer who petitioned for their permit (EFMA 1990). For WP holders, changing employers is cumbersome and costly as legislation prohibits WP applicants from residing in Singapore while their permit is being processed (EFMA 1990). The restricted ability of WP holders to re-commidify their labor power in Singapore suppresses wages by reducing competition among employers for workers (Miles 1987).

\section{THE PRODUCTION OF WAGE DISPARITY}

Notwithstanding a tremendous diversity in firm type ${ }^{7}$, daily wage rates (non-inclusive of overtime) for first-time Thai and first-time Bangladeshi Work Permit holders are remarkably uniform across Singapore's construction sector. Whereas the Thai workers that I interviewed

\footnotetext{
${ }^{7}$ Firm type includes contractors, subcontractors and labor-only subcontractors. Firms vary tremendously in size, capital composition and national origin.
} 
stated that the newly arrived Thais in their firms earn SGD23-25 per day, my Bangladeshi informants claimed that the new Bangladeshi workers earned SGD18-21 per day. It is somewhat of a mystery how the starting wages for the two national groups have achieved such consistency. The employers and the employment agencies that I interviewed stated that wages are established at the discretion of each individual employer without reference to an industry specific schedule. Singaporean bureaucrats, meanwhile, describe the divergent wage rates of first-time migrants as an outcome of what each national group "commands" on the market ('First group of', 2013).

\section{Uneven Economic Development: Bangladesh and Thailand in Contrast}

Most Thai migrants to Singapore originate in the country's Northeastern and Northern regions. Development in Thailand — which since 2011 has been classified an upper-middle income country (World Bank 2011) — has been highly uneven with most of the export-oriented manufacturing that spurred Thailand's rapid economic growth concentrated in the central region around Bangkok (Hewison 2014). Approximately half of Thailand's labor force is concentrated in the agricultural sector which generates just $8 \%$ of the country's GDP (Doner 2009). In this context in which the agricultural sectors suffers from low productivity and the manufacturing sector is unable to entirely absorb rural labor (Doner 2009), a culture of labor migration has developed across Thailand's Northern and Northeastern regions (Jones \& Pardthaisong 1999). Although peasant smallholder production remains an important source of livelihood in the rural North and Northeast, it has also become customary for male breadwinners to sell their labor outside of the village (Hickey 2013, Kitiarsa 2009). In Northern and Northeastern communities located proximate to former Vietnam-war era US military bases, a pronounced culture of international labor migration developed following the withdrawal of the military and US 
construction contractors' recruitment of former employees for building projects in the Middle East (Jones \& Pardthaisong 1999).

The majority of my Thai informants had only a primary school (6th grade education) although some had studied up to lower-secondary school (9th grade). Their accounts of their lives prior to Singapore were structured by the struggle to supplement farm income with off-farm employment in rural and urban Thailand — such as driving a tractor, factory work, breeding dogs — and in countries such as Taiwan, Israel and Saudi Arabia. The story of Som, who was 33 years old when I interviewed him in 2013 and had been working in Singapore for 11 years, is illustrative of these accounts. Som grew up on a rice farm in Udon Thani in Thailand's Northeastern Region. Although expected to help his parents regularly on the farm, Som managed to complete nine years of schooling. Som's ambition to enter technical school to become an electrician was thwarted after his parents lost their land which was signed as collateral on a failed migration attempt by Som's older brother. Citing his decision to leave technical school before even one term had elapsed as made out of sympathy [songsan] for his parents, he found work doing wiring for an electrical company, then at a Bangkok factory, then as a cleaner at a hotel before decided to migrate to Singapore at the age of 22 because he was "tired of not having money".

In Bangladesh, a low-income country (World Bank 2015a), Singaporean construction jobs presumably appeal to a larger proportion of the population. However, the pool of prospective migrants is limited by the minimum education requirement — as the trade certification test must be taken in English, completion of lower secondary school (ninth-grade) is mandatory —as well as by the hefty fees (more than SGD7000) that Overseas Testing Centres and employment agencies charge migrants for training and placement with a Singaporean 
construction firm (TWC2 2012). Bal (2013, p. 72), drawing from fieldwork conducted with prospective and returned migrants in Bangladesh, has concluded that Bangladeshi migration to Singapore is an "overwhelmingly rural middle-class" phenomenon. In Bangladesh, youth (ages 14-29) unemployment increases with each incremental level of education. The labor market is "dominated by self-employment" and young people with an education "face a long queue for the few available professional jobs" (Toufique 2014). The lack of professional opportunity in Bangladesh is resolved by select members of the rural middle-class by working blue collar jobs in Singapore. As Bal (2013, p. 72) has observed, Bangladeshi migrants to Singapore "usually come from families of 'titled' lineages which indicate that...their forebears were wealthy and influential". Distance between the blue collar worksite in Singapore and the place of residence in Bangladesh enables middle-class migrants, whose families are predominately engaged in selfemployment, to maintain the prestige of their family lineage by refraining from selling their labor on the local labor market (Rahman 2003).

About half of my Bangladeshi informants stated that their highest level of education was secondary school (10th grade). ${ }^{8}$ The other half had pursued higher education. Four of my informants had received their Bachelor degrees (in Accounting, Islamic history, Bangla, and Management) and several more had left the university before completing their degree programs in Accounting, Biology, and other fields. Only three of my informants had worked in Bangladesh. One edited video clips to earn money while he was a student, a second worked as a quality inspector in a factory, and a third was a motorcycle mechanic. Although all of my informants came from families with land, they were not expected to contribute significantly to the family farm. As one migrant explained of his contribution to the family farm, "This we don't

\footnotetext{
${ }^{8}$ In order to qualify to work in Singapore's construction industry, all Bangladeshi migrants must have at least a secondary school certificate (SSC certificate) (High Commission of Bangladesh, 2014).
} 
call work. Maybe just one hour [a day]. My father gets poor men to help [on the farm]. He pays them a little. Poor men want jobs. If we have money, we give jobs. My father doesn't want [his children] to work. We don't work. We study." Prior to migrating to Singapore, the majority of my Bangladeshi informants described themselves as "only studying".

The story of Harun, who was 28 years old and had been working in Singapore for six years when I met him in 2013, is typical of the life-history narratives of my Bangladeshi informants. Harun grew up in the Narail district of Southwestern Bangladesh where his paternal grandfather had extensive landholdings on which the family typically hired between five and fifteen laborers to grow rice, sugarcane and vegetables. Before his death when Harun was ten years old, Harun's father supplemented the family's income from agriculture with a small business. Harun's construction job in Singapore was his first. In Bangladesh, Harun's time was engaged in study and jalan jalan (Singlish for roaming around without purpose). Two years into his study for a BA in Bangla Studies, Harun decided to migrate to Singapore where he had an uncle working in the construction industry. Harun mentioned two factors as contributing to his decision to migrate. First, tension was escalating between Harun and his mother who worried that Harun's peer group was having a bad influence on him. Second, Harun had an increasing sense of the futility of education. "If you study, you have to pay a lot of money [for tuition] and then you still can't get a job. Because [in order] to work the office job in Bangladesh you have to pay money [in order to secure a position in a company]".

The above discussion has revealed certain similarities between Work Permit holders from Thailand and Bangladesh. Both groups of workers originate in rural areas and are motivated to seek work in Singapore as a consequence of a lack of satisfying employment opportunities in their home countries. Nevertheless, there are also significant differences between the two groups 
of migrants. Both 22 when they migrated to Singapore, Som had been working blue-collar jobs since the age of 15 , while Harun passed his time in his home country studying and socializing with friends. While both Som and Harun's families owned land, Som's family worked their own land, while Harun's family hired labor. The variant socioeconomic characteristics of Thai and Bangladeshi migrants reflect unevenness in economic development. Whereas Singaporean construction jobs appeal to the rural educated, middle-classes in Bangladesh, it is difficult to imagine a university educated Thai electing to perform construction work in Singapore. Moreover, by virtue of differences in the exchange rate, fees for training and job placement represent a bigger financial investment in Bangladesh than in Thailand. I will now turn to describing how the uneven development of Bangladesh and Thailand is implicated in the wage disparities of the two migrant groups in Singapore.

\section{Sending-States and Wage Policy}

Consistent with its purported allegiance to market principles, Singapore is resistant to entering into bilateral and/or multilateral agreements to regulate migration (Kaur, 2010). As such, labor-sending states have limited latitude to influence the terms and conditions under which their migrant nationals labor. Nevertheless, clear differences have emerged with regard to the extent to which Thailand and Bangladesh attempt to exercise their limited latitude. Ruhs and Martin (2006, p. 259) propose that labor "sending-country governments have the dual and sometimes competing interests of, on the one hand, promoting the rights of their nationals abroad, and, on the other, maximizing the economic benefits from emigration" such as by facilitating the export of greater numbers of workers. Differences in the Thai and Bangladeshi state's respective position on the "numbers-vs.-rights trade off" (Ruhs \& Martin 2006, p. 261) 
first became apparent in the 1970s when both states began exporting construction workers to the Middle East. In 1977, Thailand implemented a minimum wage that prospective employers in the Middle East were required to offer Thai workers (Bank, 1978, p.22). Bangladesh, likely motivated by a desire to maximize the "numbers" of migrants exported, elected to establish only "wage guidelines" that were negotiable at the discretion of the foreign employer (Hossain, 1981). Thailand did not implement a minimum wage for Singaporean employers of Thai construction labor when Thai labor first legally entered Singapore's construction industry in 1980.

Nevertheless, following a major diplomatic dispute between Thailand and Singapore regarding Singapore's treatment of undocumented Thai construction workers, a minimum wage was imposed ("Thailand sets", 1990).

Over the past two and a half decades, Thailand has periodically revised and raised the minimum wage that Singaporean employers are required to pay Thai construction workers. Since 2005, the wage has been set at SGD 23 per day (Thailand Department of Employment 2013). Bangladesh has never followed suit in establishing a minimum wage. ${ }^{9}$ While Thailand's advocacy for the wages of its workers is not particularly strong (as is evident by the stagnancy of the minimum wage for the past decade), it has obviously assumed a stronger position in this regard than Bangladesh. In the context of a discussion of the wage differentials between Thai and Bangladeshi workers, one employment agency described Bangladesh's failure to implement a minimum wage for its workers as a "great tragedy". There is not a direct causal relationship

\footnotetext{
${ }^{9}$ It is also interesting to note that while earning less (at least initially) in Singapore, most Bangladeshis also pay higher fees to recruitment agencies/training centers to secure their jobs in Singapore than Thai workers. At the time of my research in 2013, according to my interviews with Thai workers, first-time Thai migrants were charged around the equivalent of SGD 4000 to migrate to Singapore. Bangladeshis paid nearly twice this much, or according to one survey, an average of nearly SGD 7256. (TWC2 2012). According to a 2011 editorial in Bangladesh's The Daily Star, Bangladeshis are generally charged more to migrate to every destination country than workers of other nationalities migrating to the same destination, a circumstance that the Editorial Board attributes to the Bangladeshi government's poor oversight of the migration industry ("Bangladeshis pay more" 2014).
} 
between Thailand and Bangladesh's variant labor export policies and their divergent levels of economic development. After all, research on the Philippines has demonstrated the role that civil society may play in stimulating the formation of labor export policy (Rodriguez 2010). Nevertheless, Bangladesh's dependence on labor export for alleviating unemployment and earning foreign exchange currency is greater than Thailand's and to this extent the Bangladeshis bureaucrats and citizens may be more hard-pressed to advocate for protective policies which could potentially result in the loss of foreign markets for Bangladeshi labor.

\section{"One Thai is Equivalent to Two South Asians"}

According to employment agencies, Singaporean firms find the labor of "hardened Thai farmers" more conducive to realizing value than that of "Bangladeshi schoolboys". An employment agent explained that employers love Thai workers because they "take initiative" and are "hard-working". He cited one of his clients, a European multinational construction contractor with multiple large-scale projects in Singapore. "The manager says, 'Give me quality not quantity'. He said one Thai is equivalent to two South Asian workers...I don't know. I don't go to the work site, but this is what the employers tell us. They say, if they leave and say, 'Do A, B, and C', if it is a Thai worker, it will be done. If it is a South Asian worker, A will be done, but B and $\mathrm{C}$ will be left undone". A second employment agent described Bangladeshi and Indian workers as follows, "If [the supervisor is] not there, [they are] sitting. If [the] boss comes, [they are] running to do everything". In contrast, "Thais work hard, [they are] sincere". Then he goes on to explain, "Thais are farmers. They work under the sun. Bangla[deshi]s are very smart. Heavy jobs, hard jobs — they don't want. They want to clean [the worksite]”.

Like the employment agents, Thai workers' explanations of the different work habits of 
the two national groups were related with reference to anecdotes on the pace of work and the relationship between supervision (or lack thereof) and the amount of work which gets completed. Multiple Thai workers provided hypothetical examples of the disproportionate amount of labor that would be required for Thai and Bangladeshis to perform the same task. One worker stated, "say you have 20 bags that need to be moved. Bangladeshis will take a half a day or even a whole day. Thais will have it done in twenty minutes". Thai workers also posited that South Asian workers had a different relationship with time. Unlike Thai workers, South Asians would try to extend the amount of time (dung weelaa) that is required to perform tasks so as to be rewarded with overtime work. Conversely, if no overtime pay was offered, they would point to their watches and refuse to work off the clock. According to this worker's narrative, Thai workers don't mind working extra to complete tasks off the clock. Whereas Thais described South Asian workers with attributes such as lazy (kekiyat), slow-working (tom ngaan cha; dung weela) and working according to the clock (tom ngaan pen weela), when describing the labor of their own national group they used terms such as hard-working (keyun), good-at-working (tom ngan gaeng), skilled (fee meu dee, mee fee meu), capable (pen ngan), and quick-to-learn (kow jai ngai).

A couple of my Bangladeshi informants expressed an outlook on the quality of labor performed by their own national group consistent with the narratives related by many employment agents and Thai workers. Harun, the Bangladeshi worker whose life story I have shared, estimated that only $20 \%$ of Bangladeshis work hard on the jobsite. The other $80 \%$ slack off reasoning, "working can earn money, not working can also earn money". The work experience that Thais generally accumulate before migrating to Singapore may condition their bodies or teach them skills which enable them to perform at a higher level on Singapore 
construction worksites. Nevertheless, it seems more plausible that the observed difference between Thais and Bangladeshis worksite performances are largely attributable to, first, nationalgroup specific differences in the way in which blue-collar labor is perceived, and, second, a conscious strategy of resisting exploitation adopted by Bangladeshis.

I propose that in general Thais find construction labor more intrinsically rewarding than Bangladeshis. On Sundays, Thai workers congregate at the Golden Mile Complex, a derelict shopping center full of businesses catering to the Thai community. They socialize with one another in karaoke bars and by sitting in small groups within the complex and the nearby park. Thai luk tung and mo lum country music is an integral part of these gatherings, as workers play hit songs from their mobile phones and sing together in bars. The late anthropologist Pattana Kitiarsa has written on the immense trove of country songs recorded about the experiences of internal and international migrant workers beginning in the mid-1970s. He argues that these songs have been integral to shaping the identity of Thai migrant workers. Taken as a whole the songs "glorify men and reproduce images of migrant men...[of] Thailand's dominant gender ideology in which a young single man is expected to prove his manhood by earning enough money to build his own family" (2014, p. 34). Building on Pattana's argument, I would suggest that the songs glorify not only the male breadwinner but also the practice of hard, physical labor. Consider the 2003 megahit, "Have you eaten yet? (Kin Kaow Ru Yung). This song relates the story of a young woman who periodically calls her young lover who — in the original karaoke music video - is working as a construction worker in Bangkok. She tells him that she feels empathy that he must trade his sweat for money. She implores of him, "Are you resting enough? Or are you working too hard? Don't become so consumed with your goal of making money that you overwork yourself”' (Tai Orathay, 2003). Bangladeshi workers, in contrast, originate in a 
social class in which hard, physical work is not celebrated, but is instead socially stigmatized. In his ethnographic account of the social milieu of Bangladeshi migrants to Singapore, Rahman (2003, p. 108) relates, "several decades ago, villagers lived in a social world where the wealthiest landowners appeared not to work at all. They hired others to perform needed agricultural and domestic tasks. As a result...,'working' [was seen as] a sign of low status. Working for wages signified the lowest status".

Nevertheless, variance in the work ethic of Thais and Bangladeshis should not solely be interpreted as an outcome of attitudes toward manual labor developed in the labor-source country. Instead, Bangladeshis' slow pace of work may also be read as a conscience strategy adopted by some Bangladeshi workers in order to resist exploitation. Abudhallah, a researcher who for several months conducted labor processes research among Bangladeshi workers at a Singapore construction site noted that his co-workers sometimes pretended to work. His Bangladeshi co-workers referred to the simulation of work as "makework". As one worker explained (2003, p. ?), "Boss doesn’t pay us [much], we work slow, all Bangla people! We work only half'. He also observed Bangladeshi workers frequently ceasing to perform work in the absence of supervision. As he narrates, "On one occasion, two workers who were tasked to shovel granite at the site, stopped doing so immediately after their supervisors left...only to promptly resume shoveling when another worker informed them their supervisors were returning". Bal (2013) confirmed Abdhallah's findings in his observations of labor processes at one Singaporean construction firm. Bal argues that Bangladeshi workers are constantly attempting to renegotiate the "effort-reward bargain" to their advantage. When they find themselves in a company that does not reward effort with periodic wage increases, they often choose to moderate the amount of effort exerted. Instead of openly confronting their employers, 
they await the completion of their contracts while "resort[ing] to various forms of everyday resistance such as simulation and foot-dragging”. One worker told Bal that after receiving no wage increase for two years he decided to engage in "slow slow working when boss no have" . 10 One Thai worker related a story in which Bangladeshis' refusal to work was related to their lower wages vis-a-vis Thai workers. "Whenever there is something heavy to be moved, the Bangladeshis refuse to do it, saying, 'Let the people who are making the most money do the heavy work"'.

\section{THE SOCIAL ORGANIZATION OF WORK}

Surprisingly, my interviews with Thai and Bangladeshi Work Permit holders revealed that neither group of workers wish to hold the Singaporean state or Singaporean construction firms accountable for the national origin specific pay disparity. Many Thai workers described the wage differential as justified given their allegedly superior work ethic. Some Bangladeshis workers expressed dissatisfaction with the wage differential, yet they perceived the Bangladeshi government — instead of Singaporean construction firms or the Singaporean state — as the party at fault. As one Bangladeshi worker explained, "the Thailand government say, 'You must pay my worker, my people, a good salary, a higher salary.' So they pay high salary. My country no talk to Singapore, 'Give my worker good money.' The prime minister is fighting only. You know, these two political parties, fighting only." Moreover the cultivation of a sense of injustice with regard to the pay differential appears to be limited by the opinion — held by Thai workers as well as Bangladeshis - that the national origin specific pay scale is simply an attribute of the varying strengths of the different national currencies. As a Thai worker stated, "Chinese

\footnotetext{
${ }^{10}$ Unfortunately, comparable labor processes research has not been conducted on Thai construction workers in Singapore.
} 
workers, these days, can make more than SGD60 per day. But if you exchange [this amount of money] in their country, it's like the same as [if you exchange our Singaporean wages in our country]. Their currency is expensive."

While the national origin specific pay scale in Singapore's construction industry is unlikely to trigger labor unrest in the foreseeable future, it has important and wide-reaching social consequences. Fully accounting for the relationship between the national origin specific pay scale and social processes at the worksite would require research engaging a different set of methodologies than those which that I adopted. Nevertheless in my interviews with Bangladeshi and Thai workers, it became apparent that Bangladeshis are disproportionately represented in construction jobs in which the firm's profit margin is not dependent upon worker productivity such as in "worker supply" companies which temporarily supply labor to contractors at a flat rate. I only met one Thai who had worked in a supply company (in a supervisory capacity) and interviews with both Bangladeshi and Thai workers confirmed that the workers in supply companies are almost exclusively South Asian. This is a consequence of the national origin specific pay scale given firms' tendency to secure the lowest priced labor available in order to maximize profit. As worker supply companies also realize profit from the wokforce, South Asian labor's disproportionate representation in these companies indicates one way in which pay scale stratified, multinational construction guestworkforces contribute to uneven development between labor source states.

Engaging the services of worker supply companies — which range in size from a handful of workers to several hundred - enables contractors to adjust the size of their workforce to match fluctuations in workflow and thereby to shed the risk of the overrun of labor costs (Debrah \& Ofori, 1997). Supply companies in turn dictate that workers absorb the consequences of the 
industry's inconsistent labor requirements. This is illustrated by the experience of one Bangladeshi informant: "My father had a friend, an agent. This agent told me that I would work for a very good company. But then gave me a supply company, a very bad one. With the supply company, they will say, 'I need two people today'. Then in two days you are finished with the job. Then no job. Then only sleep. No job, no money. It's not the same with a main contractor. If the main contractor has no job, they still give you money. But in the supply company, no job, no money".

In interviews, workers often discussed their dread of employment with a supply company (several mentioned that before they migrated they had a relative or friend investigate a potential employer to ensure that it was not a supply company) and a couple of workers attributed their inability to profit from migration to their poor luck in being placed in a supply company. The hefty fees (an average of more than SGD7000) that prospective Bangladeshi migrant workers are charged (inclusive of training) for the arrangement of their first employment contract in Singapore means that nearly all Bangladeshi migrants regardless of company type work at a net loss of income for their first year (TWC2 2012). Nevertheless in supply companies this loss is more severe for two reasons. First, work is more infrequent in supply companies than in contractors or subcontractors. Second, supply companies commonly either refuse to renew employees' contracts (thus necessitating workers' return to Bangladesh and the probable fate of paying to arrange a second contract in Singapore) or they allow workers to renew the contract but charge SGD1500 - D2000 for this service, a hefty fee in light of the on-and-off nature of the work (TWC2 2012). While ostensibly realizing their profit from the difference between the flat daily rate charged to employers and the amount of capital required to pay, board and recruit workers, worker supply companies are certainly dependent upon rent-seeking from workers to 
remain viable. As a consequence, worker supply companies appear to be redirecting surplus from rural communities within Bangladesh and India to Singaporean firms.

\section{CONCLUSION}

In this paper, I have described how Singapore's stratified multinational construction guestworkforce is produced by the uneven development of capitalism. Consideration of the wage disparity from the perspective of neoclassical economic theory would suggest that Thais are compensated at a higher rate than Bangladeshis as a consequence of their greater investment in education and training. In contrast, I have demonstrated that a modified version of the conceptual framework developed by Burawoy (1976) and Miles (1987) is more appropriate for considering how and why pay disparities are produced within multinational guestworkforces. By tracing, first, how labor-sending and labor-receiving states use policy to contribute to the constitution of guestworker labor regimes and, second, how international migration is both appealing to and attainable by different sub-national populations as a consequence of uneven economic development, we can begin to make sense of the contradictory outcomes of capitalist economic development.

Focusing on only two of the national groups in Singapore's multinational construction workforce, this paper has offered a necessarily limited interpretation of the consequences of wage stratification for guestworkers in Singapore's construction industry. In order to achieve a more complete perspective, additional research would need to be undertaken which more fully considers all of the national groups which compose Singapore's industry. Moreover, the national origin specific pay scales of construction industries beyond Singapore should be examined. It is not an exaggeration to state that the formation of a multinational construction guestworkforce 
has been underway since the late 1970s when Asian states began to supply labor to Persian Gulf states undertaking massive petrodollar fueled development projects (Arnold \& Shah, 1986).This construction guestworkforce is multinational in both the sense that it is composed of workers from a variety of Asian labor-exporting states (including Bangladesh and Thailand) and in the sense that these worker are employed in guestworker labor regimes on construction sites in multiple Southeast Asian (mostly Singapore, Malaysia and Brunei) and Middle Eastern and North African states. ${ }^{11}$ Observers of the industry have noted the extent to which wages in guestworker construction labor markets in the Middle East are stratified according to workers' country of origin (Gunatillke 1986, Woodward 1988, Zughaibi1 1986). National origin specific pay scales have also received publicity recently in the context of the controversy over Qatar's management of labor for the 2022 World Cup (Jureidini 2014). Thai and Bangladeshi construction workers in Singapore are therefore only a small part of a larger workforce that transcends multiple national boundaries all of which deserves examination.

\footnotetext{
${ }^{11}$ The industry is also multinational in a third sense in that multinational construction contractors operate across state boundaries.
} 


\section{BIBLIOGRAPHY}

Abdullah, N. 2005. "Foreign Bodies at Work: Good, Docile and Other-ed". Asian Journal of Social Science, 33(2): 223-245.

Abdullah, N. (2001).Foreign construction workers in Singapore : the everyday life experiences of the Bangladeshis. Unpublished master's dissertation, National University of Singapore.

Arnold, F.\& Shah, N.M. (1986). Asia's labor pipeline: An overview. In (Arnold, F. \& Shah, N.M., Eds.) Asian Labor Migration: Pipeline to the Middle East. Boulder, Colorado: West View Press.

Bal, C. S. (2013). The politics of obedience: Bangladeshi construction workers and migrant labor regime in Singapore. Unpublished dissertation from Murdoch University.

Bangladeshis pay more: Set guidelines for charges. (2014, Sept 11). Editorial. The Daily Star. Retrieved from: http://www.thedailystar.net/bangladeshis-pay-more-41092

Bank of Thailand. (1978). Thai Labor Abroad. Bangkok: Bangkok of Thailand, Research Division [in Thai].

Becker, G.E. (1962). Investment in human capital: A theoretical analysis. Journal of Political Economy, 70 (5), 9-49.

Bosch, G. \& Philips, P. (2003). Building Chaos: An International Comparison of Deregulation in the Construction Industry. Routledge.

Building and Construction Authority (BCA). (2014, April 7). Overseas Testing. Retrieved from: https://www.bca.gov.sg/otc/otc_main.html

Building and Construction Authority (BCA). (2011). Construction Productivity Roadmap. Retrieved from: http://www.bca.gov.sg/newsroom/others/pr03032011_CPA.pdf

Burawoy, M. (1976). The functions and reproduction of migrant labor: Comparative material from Southern Africa and the United States. American Journal of Sociology, 81 (5), 1050 $-1087$.

De Souza, A. (1998, Sept 10). Thai workers get sports club at Beach road. The Straits Times.

Debrah, Y. A.. \& Ofori, G. (1997). Flexibility, HRM and Labour Subcontracting in the construction industry in Singapore: Can the system be refined? The International Journal of Human Resource Management, 8 (5), 690 -709.

Doner, R. F. (2009). The Politics of Uneven Development Thailand's Economic Growth in Comparative Perspective. Cambridge: Cambridge University Press.

Employment of Foreign Manpower Act, Chapter 91A, 1990 (Revised 2009).

Farmworker Justice. (n.d.). Adverse effect wage rate rule. Retrieved from: 
https://www.farmworkerjustice.org

Fee, L. \&Rahman, M. (2006). International Labour Recruitment: Channeling Bangladeshi Labour to East and South-East Asia. Asia-Pacific Population Journal, 21 (1), 85 - 107.

First group of Sri Lanka, Philippine construction workers for Sing. (2013, 26 June). Channel News Asia. Retrieved from: http://www.youtube.com/watch?v=hZPuXJGj5zs

Fong, P.E. (1992). Absorbing temporary foreign workers: The experience of Singapore. Asian and Pacific Migration Journal, 1 (3-4), 495-509.

Fong, P.E. \& Lim, L. (1982). Foreign labor and economic development in Singapore. International Migration Review, 16 (3), 548-576.

Hamid, W. (2015). Feelings of home amongst Tamil migrant workers in Singapore's Little India. Pacific Affairs, 88 (1), 5-25.

Gunatilleke, G. (1986). Introduction. In Migration of Asian workers to the Arab world. Tokyo, Japan: The United Nations University.

Hahamovitch, C. (2011). No Man's Land: Jamaican Guestworkers in America and the Global History of Deportable Labor. Princeton and Oxford: Princeton University Press.

Hewison, K. (2014). Considerations on inequality and politics in Thailand. Democratization, 21 (5), 846-866.

Hickey, M. (2013). 'Itsara' (Freedom) to work?: Neoliberalization, deregulation and marginalized male labor in the Bangkok taxi business. Asia Research Institute, Working Paper No. 204. Retrieved from: http://www.ari.nus.edu.sg/docs/wps/wps13_204.pdf

High Commission of Bangladesh, Singapore. (2014). Requirements for applying for a job in Singapore. Retrieved from: http://bangladesh.org.sg/

Hossain. A.R.M.A. (1981). Development of Manpower Export and Profile of Migrants from Bangladesh. In Labor Migration from Bangladesh to the Middle East. World Bank Staff Working Paper No. 454.

Huang, S. \& Yeoh, B.S.A. (2003). The difference gender makes: State policy and contract migrant workers in Singapore. Asian and Pacific Migration Journal. 12 (1-2): 75-97.

Jones, H. \& Pardthaisong, T. (1999). The impact of overseas labour migration on rural Thailand: Regional, community and individual dimensions. The Journal of Rural Studies, 15 (1) $35-47$.

Kam, L. W. (1999, Feb 12). Bengali paper set to hit the streets. The Straits Times.

Kaur, A. (2010). Labour migration trends and policy challenges in Southeast Asia. Policy and Society, 29(4): 385-397.

Kitiarsa, P. (2013). The "bare life” of Thai migrant workmen in Singapore. Chiang Mai, 
Thailand: Silkworm Books.

Kitiarsa, P. (2009). The lyrics of laborious life: popular music and the reassertion of migrant manhood in Northeastern Thailand. Inter-Asia Cultural Studies. 10 (3): 381-398.

Kong, M. (2007). Economic globalisation and transnationalising labor: Thai construction workers in Singapore. Labour and Management in Development , 8, 1-17.

Lim, L. (1999, Nov 24). Test for foreign workers 'too tough'. The Straits Times.

Linton, E. (2014, June 10). Millionaires per capita: Qatar leads with 17.5\%, Followed by Switzerland, Singapore. International Business Times. Retrieved from: http://www.ibtimes.com/millionaires-capita-qatar-leads-175-followed-switzerlandsingapore-1597644

Loosemore, M., \& Lee, P. (2002). Communication problems with ethnic minorities in the construction industry. International Journal of Project Management, 20(7), 517-524.

Low, S., Liu, J., \& Shan, S. (2008). Chinese Foreign Workers in Singapore's Construction Industry. Journal of Technology Management in China, 3 (2), 211-223.

Mei, L. (2010). Chinese migrant workers in Singapore: An analysis based on interviews. International Journal of China Studies, 1 (1), 194-215.

Miles, R. (1987). Capitalism and unfree labour: Anomaly or necessity? London and New York: Tavistock Publications.

Ministry of Manpower. (2014a). Foreign Workforce Numbers. Retrieved from: http://www.mom.gov.sg/statisticspublications/others/statistics/Pages/ForeignWorkforceNumbers.aspx

Ministry of Manpower. (2014b). Work permit - Before you apply. Retrieved from: http://www.mom.gov.sg/foreign-manpower/passes-visas/work-permit-fw/before-youapply/Pages/overview.aspx

Ministry of Manpower. (2013). Oral Answer by Mr Tan Chuan-Jin, Acting Minister for Manpower \& Senior Minister of State, National Development, to Parliamentary Question related to the SMRT Case. Retrieved from: http://www.mom.gov.sg/newsroom/Pages/PQRepliesDetails.aspx?listid=88

More skilled workers. (1992, May 20). The Straits Times.

New work permits: Wider choice. (1978, Dec 2). The Straits Times.

Ng, Esther. (2012, Nov 7). Not easy to marry a work permit holder. Asia One News. Retrieved from: http://news.asiaone.com/News/Latest\%2BNews/Singapore/Story/A1Story20121105381617/4.html

O’Callaghan, J. \& Lim, K. (2012, Nov. 28). Strike by China Bus Drivers tests Singapore's 
patience. Reuters. Retrieved from: http://www.reuters.com/article/2012/11/28/uksingapore-strike-idUSLNE8AR01J20121128

Ofori, G. (2002). Singapore's construction: Moving toward a knowledge-based industry. Building research and information, 30 (6), 401-412.

Ofori, G. (1997). Foreign construction workers in Singapore. Sectoral Activities Programme Working Paper. International Labor Organization.

Ong, Y. \& Yee, L. (2012, Apr 30). Supply of cheap foreign labour drying up. The Straits Times.

Rahman, M. M. (2009). In quest of golden deer: Bangladeshi transient migrants overseas. Saarbrücken, Deutschland : VDM Verlag Dr. Muller

Rahman, M. M. (2003). Bangladeshi workers in Singapore: A sociological study of temporary labor migration. Unpublished doctoral dissertation from the National University of Singapore.

Rahman, M. M. (2008). Management of Foreign Manpower. In (Fee, L.K. \& Kiong, T.C., Eds.) Social policy in post-industrial Singapore. (145- 171). Boston: Brill, 2008.

Rahman, M. M. \& Fee, L. (2005). Bangladeshi Migrant Workers in Singapore: the View from Inside. Asia-Pacific Population Journal, 20 (1).

Rodriguez, Robyn Magalit. (2010). Migrants for Export: How the Philippine State Brokers Labor to the World. Minneapolis and London: University of Minnesota Press.

Rudnyckyj, Daromir. (2004). Technologies of Servitude: Governmentality and Indonesian Transnational Migration. Anthropological Quarterly 77 (3): 407 - 434.

Ruhs, M., \& Martin, P. (2008). Numbers vs. Rights: Trade-Offs and Guest Worker Programs. International Migration Review, 42 (1): 249-265.

Siddique, A., Selvanathan, E. A., \& Selvanathan, S. (2012). Remittances and Economic Growth: Empirical Evidence from Bangladesh, India and Sri Lanka. The Journal of Development Studies, 48(8), 1045-1062.

Sullivan, G., Gunasekaran, S., \&Siengthai, S. (1992). Labour migration and policy formation in a newly industrialized country: A case study of Illegal Thai workers in Singapore. ASEAN Economic Bulletin, 9 (1), 66-84.

Surak, K. (2013). Guestworkers: A taxonomy. New Left Review 84. Retrieved from: http://newleftreview.org/II/84/kristin-surak-guestworkers-a-taxonomy

Tan, A. (2013a, Aug 23). First 20 BCA-trained Sri Lankan workers to arrive. The Straits Times.

Tan, A. (2013b, Aug 23). 'Working in S'pore will give my family a better life' The Straits Times. 
Tang, E. (1998, June 13). Laid-off Thais are returning home.

Teo, E. (1980, Nov 30). Builders can hire workers from these countries. The Straits Times.

Thailand Department of Employment (2013). Summary of Minimum Wages [in Thai]. Retrieved from: http://www.overseas.doe.go.th/

Thailand sets new rules for S'pore bosses.' Straits Times, 29 May 1990.

Transient Workers Count Too! [TWC2] (2012, August 12). Worse offfor Working: Kickbacks, intermediary fees and migrant construction workers in Singapore. Retrieved from: http://twc2.org.sg/wp-content/uploads/2012/08/Worse-off-for-working_initialreport_v2.pdf

Toufique, K. A. (2014, June). Labor market transitions of young men and women in Bangladesh. International Labor Offfice, Work4Youth Publication Series No. 13.

Vasoo, S. (1999a, Sept 10). Skills test for all foreign building workers soon. The Straits Times.

Vasoo, S. (1999b, Dec 12). Training for work in S'pore. The Straits Times.

Wong, D. (2000). Men who build Singapore: Thai workers in the construction industry. In (Chantavanich, S., Gemershausen, A. \& Beesy, A., Eds.) Thai migrant workers in East and Southeast Asia, 1996-97. Bangkok: Asian Research Center for Migration, Chulalongkorn University.

Wong, D. (1997). Transience and settlement: Singapore's foreign labor policy. Asian and Pacific Migration Journal, 6 (2), 135-167.

Woodward, P. N. (1988). Oil and Labor in the Middle East: Saudi Arabia and the Oil Boom. New York: Praeger.

World Bank. (2015a). Bangladesh. Data. Retrieved from: http://data.worldbank.org/country/bangladesh

World Bank. (2015b). Thailand. Data. Retrieved from: http://data.worldbank.org/country/thailand

World Bank (2011, August 2). Thailand now an upper middle income economy. News. Retrieved from: http://www.worldbank.org/en/news/press-release/2011/08/02/thailand-now-uppermiddle-income-economy

Zughaibi, A. M. (1987).Construction productivity in Saudi Arabia: The influence of multinational labor force (Unpublished doctoral dissertation). The University of Texas at Austin, Austin, Texas. 